\title{
An invitation to encourage due consideration for the survivability of rescued businesses in the business rescue system of England and Wales
}

Article

Accepted Version

Adebola, B. (2017) An invitation to encourage due consideration for the survivability of rescued businesses in the business rescue system of England and Wales. International Insolvency Review, 26 (2). pp. 129-152. ISSN 1099-1107 doi: https://doi.org/10.1002/iir.1274 Available at https://centaur.reading.ac.uk/71205/

It is advisable to refer to the publisher's version if you intend to cite from the work. See Guidance on citing.

To link to this article DOI: http://dx.doi.org/10.1002/iir.1274

Publisher: Wiley

All outputs in CentAUR are protected by Intellectual Property Rights law, including copyright law. Copyright and IPR is retained by the creators or other copyright holders. Terms and conditions for use of this material are defined in the End User Agreement. 


\section{CentAUR}

Central Archive at the University of Reading

Reading's research outputs online 


\begin{abstract}
$\underline{\text { Abstract }}$
Rescue seeks to preserve the going concern in a financially distressed but potentially viable business. It aims, on one hand, to maximise the value in distressed businesses and, on the other, to give potentially viable but distressed businesses the opportunity of a second chance. In England and Wales, the main rescue process is structured to strive for the former but pays relatively little attention to the latter. The mechanisms which have been introduced to maximise the prospects of the achieving a going-concern sale have been associated with the subsequent failure of the rescued business. It appears, therefore, that there is a discord between value maximisation and the survivability of rescued businesses. In 2015, the Graham review sought to alleviate this discord by proposing the voluntary independent viability report and viability statement. While this article agrees with the reforms to the extent that they encourage due consideration for the future survival of rescued businesses, it argues that the requirements ought to be mandatory. Further, that the buyer should be required to demonstrate that the amount of leverage carried forward and the time-span for repayment are calculated with due consideration for the earning capacity of the rescued business and its own operational needs.
\end{abstract}




\title{
An Invitation to Encourage Due Consideration for the Survivability of Rescued
}

\section{Businesses in the Business Rescue System of England and Wales}

\author{
Bolanle Adebola*
}

\section{$\underline{\text { Overview }}$}

Business rescue connotes giving a financially distressed but potentially viable entity a second chance to succeed, by preserving the going-concern. On one hand, rescue aims to maximise the value in distressed businesses for the benefit of the pre-distress stakeholders; on the other, it seeks to give potentially viable but distressed businesses the opportunity of a second chance. It is not expected that the business is saved from outright failure merely to fail shortly afterwards - which will be referred to as recidivism. Recidivism erodes the economic and social benefits of going-concern preservation. Its costs are disproportionately borne by the sub-set of stakeholders who stand to lose the most from the failure of the business, to wit: it undermines the second chance granted to entrepreneurs and the benefits of the job preservation given to employees; ${ }^{1}$ trade creditors not only receive little or nothing from the failure, they also lose a trading partner; the economy in general suffers the loss of a potentially valuable contributor. Ultimately, recidivism erodes trust in the rescue system. ${ }^{2}$

\footnotetext{
* Dr Bolanle Adebola is a lecturer in International Commercial Law at the School of Law, University of Reading. Foxhill House, Whiteknights road, Earley, RG6 7BA. b.adebola@ reading.ac.uk. Many thanks to the referees for their comments. I would also like to thank Professor Gerard McCormack, Professor Jay Westbrook, Dr Jorge Guira, Professor Adrian Walters and those who attended the INSOL Academics conference Sydney, for their helpful comments.

1 The Insolvency Service, Productivity and Enterprise: Insolvency - A Second Chance Cmnd 5234 (2001).

${ }^{2}$ Bully Banks http://www.bully-banks.co.uk/; J. Guthrie, 'Debt Dodgers Revel in Return of the Phoenix' (Financial Times, January 21, 2009).
} 
In England and Wales, the 'noise' about the failings of the aspects ${ }^{3}$ of the rescue system prompted an independent review commissioned by the government in 2014 which will be referred to as the Graham review. ${ }^{4}$ In addition to addressing issues relating to the transparency of aspects of the rescue process, the Graham review responded, for the first time, to the problem of recidivism which was first identified but not considered in an earlier investigation in $2007 .^{5}$ An empirical study commissioned by the Graham review -the Wolverhampton study - found that majority of the businesses that failed subsequently were characterised by going concern sales to persons with previous connections $^{6}$ to the distressed entity and going-concern sales aided by deferred ${ }^{7}$ consideration. $^{8}$

To reduce the likelihood of recidivism, the Graham review proposed reforms which came into effect in November 2015 and with which this article is concerned. ${ }^{9}$ The article argues that the orientation of the reforms sows the seeds for a more expansive view of the business rescue process. They encourage consideration for the future survival of the rescued business, a view with which this article agrees. The rescue process ought to consider both the maximisation of value for pre-distress stakeholders and the prospective survival of the rescued entity for a considerable period thereafter. When one examines the pre-2015 rescue system in England and Wales however, one

\footnotetext{
${ }^{3}$ Discussed below in Section B.

${ }^{4}$ Department for Business Innovation and Skills, Transparency \& Trust: Enhancing the Transparency of UK Company Ownership and Increasing Trust in UK Business: Discussion Paper (2013).

${ }^{5}$ T Graham CBE, 'Graham Review into Pre-pack Administration: Report to the Rt Hon Vince Cable MP, (June 2014); S Frisby, 'Report to the Association of Business Recovery Professionals: A Preliminary Analysis of Pre-Packaged Administrations' (2007), https://www.r3.org.uk/media/documents/publications/press/preliminary analysis of prepacked administrations.pdf, 79.

${ }^{6}$ See 10 below.

${ }^{7}$ See p10 below.

${ }^{8} \mathrm{n} 5$ above, A4.1.1, B4.1.1.1. Discussed further in Section C below.

${ }^{9}$ Section $\mathrm{C}$ below.
} 
finds that it is structured, mainly, to promote the maximisation of value for the predistress stakeholders but is relatively quiet on the survivability of the rescued entity. If the rescue process is to achieve its wider economic and social goals, then it ought also to facilitate the sustained survival of rescued businesses; hence, the importance of measures aimed at reducing the likelihood of recidivism.

To that end, the Graham review recommended that the buyer should present or explain its failure to present an independent viability report. ${ }^{10}$ Further, that the buyer should present or explain its failure to present a viability statement which outlines the reasons for the failure and the changes to be made to remedy them. ${ }^{11}$ The reforms apply in a specific context, namely, where there was a business rescue through a pre-packaged ${ }^{12}$ $\operatorname{administration}^{13}$ in which the buyer is connected to the distressed entity. It made no recommendation in relation to deferred consideration, however. It is at this point that this article departs from the Graham review and its reforms. It argues that a clear determination of the amount of leverage that can be carried forward successfully by the business is also fundamental to its survival. Hence, there is the need to extend the reforms to the use of deferred consideration. The buyer ought to demonstrate that the stated sum and repayment plan are calculated with due regard for the earning capacity of the rescued business and its own operational requirements. ${ }^{14}$ Further, The article

\footnotetext{
${ }^{10}$ See p 11 below.

${ }^{11}$ See p11 below.

${ }^{12}$ See $\mathrm{p} 7$ below.

${ }^{13}$ See p6 below.

${ }^{14}$ Section D.
} 
argues for a more stringent approach. It argues that the requirements ought to be obligatory, not voluntary. ${ }^{15}$

It may be argued that the introduction of additional requirements to the rescue process will complicate the rescue process and introduce additional costs at a point when the distressed entity has little or no funds available to it. In response, it is argued that the managers of distressed entities are already encouraged to undertake independent investigations and seek independent advice in the course of rescue. ${ }^{16}$ The proposals merely require them to demonstrate that they have. It is expected that the previouslyconnected persons would be able to access the necessary funds to cover their costs if they can demonstrate a viable business and workable plan to potential lenders and investors. In addition, considering that almost $40 \%$ of the businesses rescued with the use of deferred consideration fail again, it is important to ensure that the buyer obtains independent and relevant advice during the negotiations; particularly because the insolvency practitioner is not obliged to negotiate in the interests of the buyer or the future of the rescued business. Her goal is to maximise the value accruing to the predistress stakeholders, even if the deal is detrimental to the rescued business. ${ }^{17}$ Ultimately, the proposals seek to encourage the buyers to take a pro-active and objective approach to business rescue than is presently the case.

The article is divided into 6 sections. Section B sets out a brief overview of the development and orientation of the main business rescue procedures in England and

\footnotetext{
15 Section E.

${ }^{16}$ SIP $16, \quad$ paragraph 02015.pdf accessed 06/12/2016.

${ }^{17}$ Insolvency Act 1986, Schedule B1, para 3(2).
} 
Wales. Section $\mathrm{C}$ discusses the links between the rights of lenders and the rescue system. It discusses the modern challenges faced at business rescue in England and Wales today, as set out by the Graham review and outlines the reforms proposed as remedy. Section $\mathrm{D}$ discusses the relevance of the reforms to the rescue process. It adduces reasons why the buyer ought to be required to demonstrate that it has received independent relevant advice on the main issues which have been identified: viability, operational plan and leverage carried forward. Section E introduces suggestions that are believed, would improve the effectiveness of the business rescue system. Section F sets out the conclusions. Essentially, it reiterates its argument for a broader look at the rescue process and the introduction of elements which would encourage due consideration for the future survival of the rescued business.

\section{A. An Overview of Business Rescue in England and Wales}

In England and Wales, the rescue concept was formally introduced into the insolvency system on the recommendation of the Cork committee. ${ }^{18}$ The committee advocated for the preservation of distressed businesses that can contribute to the economy. ${ }^{19}$ For that reason, the insolvency system and culture were reformed to encourage rescue through a suite of rescue processes including the administrative receivership procedure, ${ }^{20}$ the administration procedure ${ }^{21}$ and the company voluntary arrangement. ${ }^{22}$ Administrative receivership became the most pervasive business rescue mechanism in the following

\footnotetext{
${ }^{18}$ Insolvency Law and Practice: Report of the Review Committee Cmnd 8558 (1982).

${ }^{19}$ Ibid, Chapter 4, [53].

${ }^{20}$ Insolvency Act 1986, Part III, s 42 - s45.

${ }^{21}$ Insolvency Act 1986, Part II.

${ }^{22}$ Insolvency Act 1986, Part 1.
} 
decade. ${ }^{23}$ It finds its roots in the contractual remedies afforded to the holder of proprietary rights in the debtor's assets. ${ }^{24}$ It can only be initiated by the secured creditor with proprietary rights over the whole or substantially the whole of the debtor's assets where those rights include rights granted by a floating charge; to be referred to as the senior lender in this article. $^{25}$ The procedure is contractual and executed administratively; requiring minimal court involvement. ${ }^{26}$ The appointee must be an insolvency practitioner. ${ }^{27}$

To facilitate the execution of her duties, the administrative receiver is contractually endowed with management powers, including the default provisions set out in schedule 1 to the Insolvency Act 1986. The goal is to maximise the value in the assets. In principle, at least, the administrative receiver is to decide whether value is best maximised by liquidation or by the preservation of the going concern. ${ }^{28}$ Nevertheless, she is not obliged to run the business or sell it as a going concern, even though she would usually have the power to do so. ${ }^{29}$ Her duty is to act in the best interests of her appointor. ${ }^{30}$ The administrative receiver is not accountable to the other stakeholders in the distressed entity. While she has the duty to report on some matters to the unsecured creditors, she cannot be instructed by them; neither is she required to consider their

\footnotetext{
2323 The Insolvency Service, 'Receiverships, Administrations and Company Voluntary Arrangements in England and Wales, 1987 to Present' http://webarchive.nationalarchives.gov.uk/20140311023846/http:/www.insolvencydirect.bis.gov.uk/other information/statistics/historicdata/HDmenu.htm (last assessed 04/04/2017).

${ }^{24}$ Gaskell v Gosling[1896] 1 QB, 669.

${ }^{25}$ Insolvency Act 1986, s 29 (2).

${ }^{26}$ S Davydenko and J. Franks, 'Do bankruptcy codes matter? A study of defaults in France, Germany and the UK', http://papers.ssrn.com/sol3/papers.cfm?abstract id=647861.

${ }^{27}$ Insolvency Act 1986, s230(2).

${ }^{28}$ Cork on Cork: Sir Kenneth Cork takes Stock with Hugh Barty-King (Macmillan London, 1988).

${ }^{29}$ Downsview Nominees Ltd [1993] 3 All ER 626; Medforth v Blake [1999] BCC 771.

${ }^{30}$ re B Johnson \& Co (Builders) Ltd [1955] Ch. 634.
} 
interests when executing her functions. ${ }^{31}$ Her appointment displaces the pre-distress management of the distressed entity. ${ }^{32}$ At best, they can exercise functions delegated to them or powers which the receiver declines to enforce.

In practice, administrative receivership usually led to the outcome which was preferred by the senior lender. ${ }^{33}$ This fact has attracted differing views by experts in the field. Armour and Frisby are proponents of the view that the advantages of the administrative receivership process were under-appreciated. ${ }^{34}$ They have pointed to the control powers given to the senior lender as a principal advantage of the procedure. ${ }^{35}$ They have argued that the wealth of information obtained through the extensive monitoring powers granted contractually to the senior lender, as well as its ability to effectively channel the information gathered into decisive actions on the timely commencement, choice of administrative receiver and a clearly determined outcome cumulatively reduced the costs of corporate distress.

Nevertheless, the practice was heavily criticised by others who focused on the perverse incentives of the administrative receiver. ${ }^{36}$ It has been demonstrated that the administrative receiver was obliged to pursue the strategy preferred by the senior lender if she was to garner future appointments. ${ }^{37}$ Mokal argued that this strategy resulted in

\footnotetext{
${ }^{31}$ Insolvency Act 1986, s 48, s49; Downsview Nominees Ltd [1993] 3 All ER 626.

32 Gomba Holdings UK Ltd v Homan (1986) 1 WLR 1301.

33 Office of Fair Trading, 'The market for corporate insolvency practitioners: A market study' (June 2010)

http://webarchive.nationalarchives.gov.uk/20140402142426/http:/www.oft.gov.uk/shared_oft/reports/Ins olvency/oft1245 accessed 13/12/2016.

${ }^{34}$ J Armour and S Frisby, 'Rethinking Receivership' [2001] 21 Oxford Journal of Legal Studies 733.

35 Ibid, 86-91.

36 Department of Trade and Industry, A Review of Company Rescue and Business Reconstruction Mechanisms (2000).

37 Office of Fair Trading, 'The market for corporate insolvency practitioners: A market study' (June 2010)
} 
the undue liquidation of distressed entities that may otherwise have been rescued. ${ }^{38}$ In his view, the senior lender would only push for the preservation of the going concern where it was unlikely to recover the value of its loan in full. The decision whether or not to preserve the going concern was based not on the professional judgement of the practitioner but on the proclivities of her appointor. The higher the likelihood that the senior lender could recover in full even with a piece-meal sale, the lower the prospect of going concern preservation. Consequently, it was alleged that the focus on the economic interests of the senior lenders trumped the economic and social interests of other stakeholders to the detriment of value-maximization.

On account of the criticisms, the government opted to reform the insolvency law to promote greater balance in the interest of a wider group of stakeholders, as the new millennium rolled in. ${ }^{39}$ The government at the time encouraged changes along the path of the rescue system of the United States which is generally perceived to have a debtororiented system and a strong rescue ethic. ${ }^{40}$ The reforms came within the broader policy of promoting entrepreneurship and the preservation of jobs for the ultimate growth of the economy. ${ }^{41}$ It followed that by 2003 , reforms to the rescue system saw the administrative receivership process largely restricted. ${ }^{42}$ The administration procedure,

http://webarchive.nationalarchives.gov.uk/20140402142426/http:/www.oft.gov.uk/shared_oft/reports/Ins olvency/oft1245.
38 R Mokal, 'The Harm Done by Administrative Receivership' http://papers.ssrn.com/sol3/papers.cfm?abstract id=568702 last accessed 11/12/2016, 4-6.
${ }^{39}$ I Fletcher, 'UK Corporate Rescue: Recent Developments - Changes to Administrative Receivership, Administration, and Company Voluntary Arrangements - The Insolvency Act 2000, The White Paper 2001, and the Enterprise Act 2002' (2004) 5 European Business Organization Law Review 119.
${ }^{40}$ G McCormack, 'Control and Corporate Rescue - An Anglo-American Evaluation' (2007) 56 International and Comparative Law Quarterly 515.
${ }^{41} \mathrm{n} 1$ above, 2.1 .
${ }^{42}$ Insolvency Act 1986, Part III, Chapter IV, s 72A. 
formerly a court-reliant rescue process executed on behalf of the stakeholders as a whole, was streamlined and promoted to the role of the rescue option of choice. ${ }^{43}$

Today, the administration procedure can be initiated in or out of court by a number of actors including the directors and the senior lender. ${ }^{44}$ In principle, by enabling the directors to initiate rescue out of court, they would exercise potent control rights. Given that the appointment of the administrator does not completely remove them from office, it was expected they would welcome the chance to initiate the rescue mechanism in a timely-fashion and appoint an administrator of their choice. Both factors would in turn boost the chances of successful rescue.

In the spirit of going-concern preservation, the primary objective of the administrator is to rescue the company. ${ }^{45}$ It is only where the administrator thinks that the company cannot be rescued, or that a better outcome can be achieved for the creditors that other ends can be prioritised. The next objective of the administrator would be to achieve a better outcome than would have been achieved if the company had not gone first into administration. ${ }^{46}$ In principle, the administrator would try to maximise value by negotiating a going-concern sale. Where the administrator thinks that neither of the first two objectives can be achieved, or that undue harm will not be done to the other creditors, then administration may be commenced merely to make distributions to a subset of the stakeholders of the debtor company. ${ }^{47}$ In practice, the streamlined

\footnotetext{
${ }^{43}$ n 1 above, $2.7-2.17$.

${ }^{44}$ Insolvency Act 1986, Schedule B1, Para 12, Para 14, Para 22.

${ }^{45}$ Ibid, Para 3 (1) (a).

${ }^{46}$ Ibid, Para 3 (1) (b), (3).

${ }^{47}$ Ibid, Para 3 (1) (c), (4).
} 
administration does not rescue companies, however. ${ }^{48}$ At best, it seeks to achieve a better outcome for the creditors than might have been otherwise attained. The ultimate goal is therefore value-maximisation for the pre-distress creditors.

The administrator is to perform her tasks in the interest of all the creditors as a whole. ${ }^{49}$ The administrator is accountable to the unsecured creditors, who vote on her proposals and may seek redress against decisions that have been or will be taken. ${ }^{50}$ However, a practice which became known as the pre-pack which had quietly been gaining traction shortly after the new Act went into force, came into its own in the post-reform era. ${ }^{51}$ The first detailed investigation into the pre-packed administration procedure set the percentage of pre-packs upwards of 35.5\%. ${ }^{52}$ The 2014 investigation into pre-packed administrations shows that they account for the greatest proportion of going-concern sales. ${ }^{53}$

Essentially, the pre-pack finds its roots in the proprietary remedies granted to the senior lender by contract. ${ }^{54}$ Unlike with the usual administration procedure in which the administrator is expected to determine the outcome of each case after appointment, the outcome of the pre-packed administration is decided before a formal insolvency process

\footnotetext{
${ }^{48}$ S Frisby, 'Report on Insolvency Outcomes' (2006), 58.

${ }^{49}$ Ibid, Para 3(2).

50 Ibid, Para 49, Para 53.

${ }^{51}$ Discussed further in Section B.

52 S Frisby, 'Report to the Association of Business Recovery Professionals: A Preliminary Analysis of Pre-Packaged Administrations' https://www.r3.org.uk/media/documents/publications/press/preliminary_analysis_of_prepacked_administrations.pdf, (accessed 09/04/2017), Part 1, 15.

${ }^{53} \mathrm{P}$ Walton and C Umfreville, Pre-pack Empirical Research: Characteristic and Outcome Analysis of PrePack Administration, 85.

54 V Finch, 'Pre-Packaged Administrations: Bargains in the Shadow of Insolvency or Shadowy Bargains?'(2006) JBL, 568.
} 
is initiated. The practitioner is appointed principally to formally implement it. ${ }^{55}$ The process is concluded without the presentation of proposals to or input from the unsecured creditors; scaling back the participatory right administration grants to them. ${ }^{56}$ The process does not require an order of the court to be valid. ${ }^{57}$ In essence, the pre-pack functionally replaces the administrative receivership procedure which the government sought to restrict with the 2002 reforms. ${ }^{58}$

Like administrative receivership, the pre-pack procedure is regarded with suspicion by some and has been criticised for excluding the participatory rights of unsecured creditors. ${ }^{59}$ Over the years, the government has sought to improve both its transparency and credibility. To that end, the Statement of Insolvency Practice 16 (SIP 16) was introduced in $2009 .{ }^{60}$ Statements of Insolvency Practice are guidance notes issued to help insolvency practitioners maintain standards in the insolvency practice. SIP 16 obligates the practitioner to provide information about the pre-pack sale to unsecured creditors after its conclusion. There is no liability attached to the breach of the statements.

\footnotetext{
${ }^{55}$ Re T\&D Industries [2000] 1 BCLC 471; Re Transbus International [2004] EWHC 932 (Ch).

${ }^{56}$ P Walton, 'Pre-packaged Administration - Trick or Treat?' (2006) Insolvency Intelligence 113.

57 re NS Distribution [1990] B.C.L.C. 169; re Charnley Davies Ltd [1990] B.C.C. 605.

${ }^{58}$ A Walters, 'Statutory Erosion of Secured Creditors' Rights: Some Insights from the United Kingdom' [2015] University of Illinois Law Review, 543.

59 J Moulton, 'The Uncomfortable Edge of Propriety--Pre-packs or Just Stitch-ups?' (2005) Recovery (Spring), 2 but see R Singh, 'Jon Moulton Makes U-Turn on Pre-Packs' (Accountancy Age, 18/06/2010). 60 SIP $16 \quad$ (2009, $\quad$ Version 1$)$ https://www.r3.org.uk/media/documents/technical_library/SIPS/SIP\%2016\%20E\&W.pdf accessed on $11 / 12 / 2016$. Prior to the 2015 reforms, it was revised in 2013. SIP 16 (2013, Version 2) https://www.r3.org.uk/media/documents/technical_library/SIPS/SIP 16 Version_2_(effective from 1_November_2013).pdf
} 


\section{B. The Modern Challenges of Business Rescue}

From the above, it is clear that the predominant business rescue process in England and Wales is contractualist in orientation. While England and Wales is the poster child for contractualist rescue systems, even traditionally more inclusive systems like that of the United States ('US') have experienced a surge in contractualist practices since the turn of the millennium. ${ }^{61}$ Scholars attribute the surge to the strengthening of senior lender control. $^{62}$ By the time a company files for Chapter 11 protection, it is usually highly leveraged and lacking unencumbered assets. ${ }^{63}$ Finance is therefore required to keep the company running. The creditors who provide such finance are placed in prime position to control the ensuing sequence of events and consequently, the outcomes of the process. These lenders also provide finance for the company after the formal commencement of rescue called Debtor-in-Possession Finance (DIP Finance).

Lenders who provide finance as the company approaches insolvency and after the commencement of the Chapter 11 process can push for the liquidation of all the assets of a distressed company through a s363 sale. ${ }^{64}$ In the US, unlike in England and Wales, a court order is required to sanction the sale. ${ }^{65}$ This gives the court some oversight

\footnotetext{
${ }^{61}$ S Cook and G Franklyn, 'In Re Skymall: The Crash of SkyMall and the Take Off of 363(b) Sales' [2016] http://trace.tennessee.edu/cgi/viewcontent.cgi?article=1042\&context=utk_studlawbankruptcy; J Lipson, 'Governance in the Breach: Controlling Creditor Opportunism' (2011) 84 Southern California LR 1035; B Erens and D Hall, 'Secured Lender Rights in 363 Sales and Related Issues of Lender Consent' [2010] 18 ABI Law Review, 535.

${ }^{62}$ D Skeel Jr, 'Creditors' Ball: The "New" New Corporate Governance in Chapter 11' (2003) 152 Uni Penn LR 917.

63 R Thomas, 'Tipping the Scales in Chapter 11: How Distressed Debt Investors Decrease Debtor Leverage and the Efficacy of Business Reorganization' (2010) 27 Emory BDJ213;

${ }^{64}$ M Jacoby and E Janger, 'Ice Cube Bonds: Allocating the Price of Process in Chapter 11 Bankruptcy' [2014] 123 Yale Law Journal 862.

${ }^{65} 11$ USC, s363 (b) (1).
} 
because of its discretion to approve or reject the application for sale. ${ }^{66}$ In practice, the court is constrained in the exercise of this discretion because the applicants typically present the case as one with great urgency. ${ }^{67}$ The distressed company is depicted as a melting ice-cube which is haemorrhaging value every day. ${ }^{68}$ To prevent further loss of value, the court feels compelled to sanction the sale, however reluctant the judge might be to do so. ${ }^{69}$ Such a sale, particularly where it is for all of the company's assets, circumvents the traditional chapter 11 process and the protections that are in-built for the benefit of other stakeholders. Such that, like in England and Wales, the process is concluded with the participation, consent or at least acquiescence of the senior lenders and their nominees but not that of the other stakeholders. ${ }^{70}$

It is difficult to determine empirically the reasons for pre-packs because the parties require no formal sanction from the court to undertake a pre-pack. We nevertheless can deduce some of the reasons for the use of pre-packs by assessing the available case law, empirical research and scholarly opinions. ${ }^{71}$ Many pre-pack cases fit within the "no time to spare' or 'melting ice-cubes' category. The first cases of the pre-pack occurred within the first few weeks that the Insolvency Act 1986 came into force. On the $16^{\text {th }}$ of January, 1987, less than three weeks after the new Act came into force, a petition was

${ }^{66}$ re Lionel Corp., 722 F.2d 1063 (2d Cir 1983).

${ }^{67}$ D Skeel, 'Competing Narratives in Corporate Bankruptcy: Debtor in Control vs. No Time to Spare' [2009] Michigan State Law Review 1187.

68 re On-Site Sourcing, Inc., 412 BR 817 (Bankr ED Va 2009); re Chrysler LLC, 576 F.3d 108 (2d Cir 2009).

${ }^{69}$ n 64, $886-888$.

70 A Raykin, 'Section 363 Sales: Mooting Due Process?' [2012] 29 Emory Bankruptcy Development Journal 91; K Rosen, 'Section 363 Has Become An Alternative That Poses Problems' https://www.law360.com/articles/768436/section-363-has-become-an-alternative-that-poses-problems (accessed 09/04/2017); B Adler V Capkun and L Weiss, 'Value Destruction in the New Era of Chapter 11 ' [2013] 29 Journal of Law, Economics and Organization, 461.

${ }^{71}$ The categories discussed below are not exhaustive. See also, n52 above, 32-33. 
presented to place Charnley Davies Ltd into administration. ${ }^{72}$ By the $28^{\text {th }}$ of January, 1987, the administrator had entered into transactions for the sale of all three businesses without placing his proposals before the creditors of the company. Before entering into the sales agreements, the administrator made an application to the court for directions and also made an appointment to see the representatives of some of the creditors of the company for whom the company had acted as agent. The administrator cited insufficient time as the reason why he could not call a meeting of creditors. ${ }^{73} \mathrm{He}$ argued that the company was in the insurance business and that such businesses depend on the goodwill of their clients and the willingness of the brokers and the staff to stay in the company's employ. Thus, a timely sale was deemed necessary. ${ }^{74}$

Some other pre-packs fall under the 'lack of trading finance' category. ${ }^{75}$ These prepacks are necessary because the administrators lack the funds to run the business while proposals are prepared and placed before the creditors for a vote. In DKLL Solicitors $v$ HM Revenue \& Customs $^{76}$ an application was made for the appointment of an administrator to give effect to a pre-pack by which the distressed business could be salvaged. The plan was to sell the business to a newly incorporated limited liability partnership as soon as administration commenced; before proposals could be placed before creditors. It was stated that the pre-pack was necessary because the funds by which an administrator could trade the business was not available. In England and Wales, many companies that go into administration are small or medium sized which find it difficult to access additional finance when distressed. Further, they tend to lack

\footnotetext{
${ }^{72}$ In re Charnley Davies ltd (1988) 4 BCC 152

${ }^{73}$ Ibid, 155; [1990] BCC 605, 606.

${ }^{74} \mathrm{n} 52$ above, 32.

${ }^{75}$ Re Kayley Vending Ltd [2009] EWHC 904 (Ch); n 52 above, 32.

${ }^{76}$ [2007] EWHC 2067 (Ch).
} 
unencumbered assets and the reality of the floating charge is that newly acquired assets come under the charge where carefully worded; hence, the need for quick sales.

A third category of cases may be described as the 'no better outcome' pre-pack. In these cases, it is argued that the pre-pack offers the best outcome for the business. ${ }^{77}$ In $r e$ Kayley Vending $L t d^{78}$, a company which supplied cigarette vending machines to public houses became unable to pay its debts and faced the prospect of liquidation. The company had proposed a voluntary arrangement to its creditors but it had been rejected. The company applied for an administration order to enable a pre-pack sale of the business to potential buyers who had offered the highest value for the assets. The alternative was a piece-meal liquidation which would have generated less value for the creditors. ${ }^{79}$

In 2003, the number of pre-packs rose sharply. ${ }^{80}$ Various explanations have been adduced for the upsurge. ${ }^{81}$ In particular, there was an increase in the use of asset-based finance. ${ }^{82}$ The upsurge in this type of finance was influenced by the outcomes of re Spectrum Plus ${ }^{83}$ which set-out the hurdles to creating a flexible but valid fixed charge over receivables; requiring the city to change its funding practices in that regard. ${ }^{84}$

\footnotetext{
${ }^{77}$ Re Consumer \& Industrial Press Ltd. (No. 2) (1988) 4 BCC 72.

78 [2009] EWHC 904 (Ch).

${ }^{79} \mathrm{n} 52$ above, 33.

${ }^{80} \mathrm{n} 52$ above, Part I, 15-21.

${ }^{81}$ J Armour, 'The Rise of the "Pre-Pack": Corporate Restructuring in the UK and Proposals for Reform' http://papers.ssrn.com/sol3/papers.cfm?abstract_id=2093134, accessed 20/09/2016.

${ }^{82} \mathrm{~K}$ Akintola, 'What is Left of the Floating Charge? An Empirical Outlook' (2015) Butterworths Journal of International Banking and Financial Law 404.

83 [2005] UKHL 41, [2005] 2 AC 680.

84 J Armour, 'Should We Redistribute in Insolvency?' in J Getzler and J Payne (eds), Company Charges: Spectrum and beyond (OUP, 2006), ch 9; J Marshall, 'Charges on book debts: a wasted opportunity?' https://uk.practicallaw.thomsonreuters.com/9-2010620? IrTS=20170409075202636\&transitionType=Default\&contextData=(sc. Default) \&firstPage=true \&bhcp=1 (accessed 09/04/2017).
} 
These developments have introduced fragmentation into the financing of companies and complexities to the negotiations during business rescue. ${ }^{85}$ To prevent the costly consequences of complicated and potentially protracted negotiations, the pre-pack could be agreed before formal notification of the company's insolvency to other stakeholders.

In all categories of the pre-pack, as with other contractualist processes, the disenfranchisement of creditors does not extend to the senior lenders who directly or indirectly determine the outcomes of the process. This presents a problem which has been criticised by some scholars. It has been argued that senior lenders and their nominees will implement these private decisions even if they do not maximise the value locked in the assets of the distressed entity. Thus, they would, for example, be unwilling to delay the sale to recover a higher sum, even if it would result in higher returns for the other stakeholders. ${ }^{86}$ Similarly, they may choose a quick piece-meal sale over a goingconcern sale where the former returns a value that exceeds the secured loan. ${ }^{87}$ For that reason, Westbrook argues that senior lenders have a liquidation bias because they are likely to push for the liquidation of the assets where it is the most efficient option for them. ${ }^{88}$

Ayotte and Morrison argue that the choice of outcomes is inversely related to the loanto-value ratio. ${ }^{89}$ Using empirical methods, they demonstrate that senior the lenders are more likely to seek quick enforcement where the value of the security will repay their

\footnotetext{
${ }^{85} \mathrm{n} 82$ above, 404-405.

${ }^{86}$ R Mokal, Corporate Insolvency Law: Theory and Application (Oxford: OUP, 2005), 210-211.

87 E Morrison, 'Bargaining around Bankruptcy: Small Business Workouts and State Law' (2007) http://papers.ssrn.com/sol3/papers.cfm?abstract_id=1065543, accessed 25/07/2016.

${ }^{88} \mathrm{~J}$ Westbrook, 'The Control of Wealth in Bankruptcy', [2004] 82 Texas Law Review 795, 844.

${ }^{89} \mathrm{~K}$ Ayotte and E Morrison, 'Creditor Control and Conflict in Chapter 11 Bankruptcy' [2009] 1 Journal of Legal Analysis, 511.
} 
debt in full - in essence, where they are over-secured..$^{90}$ The interests of the senior lenders are aligned with the other interests only where the value of the security will not repay the outstanding sums owed to the senior lender in full - where they are undersecured. It is only in such cases that the senior lenders will seek to maximise the value in the assets. ${ }^{91}$ Given their perception of the state of affairs, these scholars grapple with the challenge of ensuring that the rescue process aligns the interests of the senior lenders and their nominees with those of the wider stakeholders in the distressed business. However, while scholars like Westbrook criticise the use of contractualist systems in general, others like Jacoby prefer to recommend changes that would protect the wider interests in the distressed company, while facilitating quick resolution of distress in cases that genuinely require it. ${ }^{92}$

Another group of scholars contend that senior lenders have, in contrast to the abovestated opinion, a going-concern bias. ${ }^{93}$ That school of thought argues that senior lenders are interested in the preservation of the going-concern of distressed businesses; not liquidation. Polo, for example, argues that they are likely to recover substantial proportions of the debt only where the going concern is preserved and adduces empirical evidence to that effect. ${ }^{94}$ In fact, this going-concern bias of senior lenders is said to be at the heart of the creation of innovative processes that facilitate rescue. One of these has been described by Franks and Sussman, who argue that senior lenders do

\footnotetext{
${ }^{90}$ Ibid, 533-538.

${ }^{91}$ Ibid, 533-538.

92 n 64 above, 889.

93 S Djankov, O. Hart, C. McLiesh and A Shleifer, 'Debt Enforcement around the World' http://papers.ssrn.com/sol3/papers.cfm?abstract id=953000\&rec=1\&srcabs=428042\&alg=7\&pos=1 last accessed 20/09/2016.

94 A Polo, 'Secured Creditor Control in Bankruptcy: Costs and Conflict' http://papers.ssrn.com/sol3/papers.cfm?abstract_id=2084881, last accessed 20/09/2016.
} 
not enforce their security as soon as the debtor becomes distressed. ${ }^{95}$ They argue that these types of lenders tend to have a Business Support Unit through which distressed debtors can be supported. ${ }^{96}$ Viable entities are returned to branch while their less viable counterparts are sent into a debt recovery unit. Likewise, Armour asserts that the prepack process was also developed on account of this going-concern preservation proclivity of senior lenders..$^{97}$

To increase the number of going-concerns that are preserved during administration, senior lenders in England and Wales and their nominees have, since the turn of the millennium, encouraged sales of distressed businesses to those previously-connected to the insolvent company where they are not responsible for the previous failure of the business. ${ }^{98}$ Previously-connected persons include the owners and/or management of the pre-distress company and those associated with them. ${ }^{99}$ Following the credit crisis, the armoury of the pre-pack was further extended to include the use of deferred consideration. ${ }^{100}$ By this, the business is sold to a new company which then undertakes to pay the purchase price within a specified period; typically less than 12 months but up to 36 months, in some cases. ${ }^{101}$

The Wolverhampton study showed that the use of deferred consideration and sales to previously-connected persons are more likely in the case of pre-packs, where the decisions are made privately by the senior lenders and their nominees, than in the case

\footnotetext{
95 J Franks and O Sussman, 'Financial Distress and Bank Restructuring of Small to Medium Size UK Companies' http://papers.ssrn.com/sol3/papers.cfm?abstract_id=428042, last accessed 20/09/2016.

${ }^{96}$ Discussed further in Section C.

${ }^{97} \mathrm{n} 81$ above, 15.

98 Ibid, 16.

${ }^{99} \mathrm{n} 97$ above, 16; n 5 above, 9.5.

100 n 5 above, 40 .

${ }^{101} \mathrm{n} 53$ above, A2.2
} 
of trading administrations where the unsecured creditors get a vote on the proposals of the administrator. ${ }^{102}$ As was stated in the Wolverhampton study:

- Connected Sale and Deferred Consideration were present (either individually or together) in $77.0 \%$ of all cases, and hence both were absent in $23.0 \%$ of all cases. (This contrasts sharply with the Trading Administration data where both were absent in $63.4 \%$ of all cases - see analysis in Section B4 below).

- Both Connected Sale and Deferred Consideration were present in $44.6 \%$ of all cases, (as opposed to only $8.6 \%$ in the trading administration data). ${ }^{103}$

An empirical study of prepacks in 2007 revealed, however, that $48.6 \%$ of businesses rescued by previously-connected persons failed subsequently; in contrast to $28.5 \%$ of those rescued by their non-connected counterparts. ${ }^{104}$ Similarly, the Wolverhampton study found that $30 \%$ of businesses rescued by pre-pack sales to previously-connected persons failed within the subsequent 36 months; as opposed to $18.4 \%$ of those sold to their non-connected counterparts. ${ }^{105}$ Further, the Wolverhampton study found that $39 \%$

\footnotetext{
102 n 53 above, B4.1.1.

${ }^{103}$ Ibid, A4.1.1. Emphasis mine. Also, B4.1.1.

104 n 52 above, 79 .

105 n 53 above, A.4.1.2.
} 
of the businesses rescued through deferred consideration failed again within 36 months; in contrast to $9.7 \%$ of those saved without deferred consideration. ${ }^{106}$

These recidivism figures introduce another element to the criticisms of the pre-pack. The innovations introduced by senior lenders and their nominees have been implicated in the subsequent failure of rescued businesses. Further, these two innovations are more likely to be used where the other creditors are not given a vote on the administrator's proposals. As stated in the Graham review:

Even though at face value it appears that a higher percentage of pre-pack purchases subsequently failed than did trading administrations, this seems to be because a higher percentage of pre-packs have characteristics associated with failure (i.e. connected sales and deferred consideration). When controlling for these factors, and comparing pre-packs and trading administrations on a like-for-like basis, the data shows that the odds of failure are lower for pre-packs. ${ }^{107}$

It is argued the mechanisms introduced by senior lenders and their nominees introduce complex problems. Much of the debate on rescue processes have focused on the misalignment of interests between the senior lenders and other stakeholders in the company. This article focuses on another but related issue. It discusses the tension between value maximisation in distressed entities and the survivability of rescued

\footnotetext{
106 Ibid, A4.1.2.

${ }^{107}$ n 5 above, 7.90; emphasis mine.
} 
businesses. As can be observed from the earlier discussion, the pre-pack undoubtedly facilitates business rescue in some cases. Nevertheless, the recidivism figures highlight the tension between value maximisation in distressed entities and post-rescue survival.

It is argued that this tension goes to the very heart of business rescue because the figures reveal that sales to previously-connected persons even where coupled with the traditional administration at which unsecured creditors vote on the administrator's proposals are still likely to fail subsequently. Similarly, sales with deferred consideration even where coupled with traditional administration or with sales to those without previous connections to the business will result in subsequent failure. The challenge therefore is how the policy-maker can ensure that the rescue process balances the quest for value-maximisation with the desire to have sustained business rescues. A balanced system will not only achieve the broader goals of rescue but will also reduce recidivism and promote trust in the rescue system as a whole. It is with this challenge that the rest of The article grapples.

C. Striking a Balance between Value Maximization and Future Survival in the $\underline{\text { Rescue Process }}$

As can be expected, the Graham review was concerned about the rate of recidivism. ${ }^{108}$ To that end, she made recommendations targeted at recidivism reduction. These recommendations were predicated on the normative opinion that there is an inherently future-focused element of business rescue. ${ }^{109}$ They signify a long-term view of the rescue practice and its purpose, rather than a short-term view which focuses solely on

\footnotetext{
${ }^{108} \mathrm{n} 5$ above, 3.1.1.

109 Ibid,
} 
the conclusion and execution of the business sale. Indeed, it is difficult to deny the future-focused element of rescue. Short-term rescues trigger criticisms of debt-dumping and phoenixism which ultimately undermine trust in the rescue system. ${ }^{110}$ Debtdumping refers to the practice whereby those with previous connections to distressed business shed pre-distress debts by liquidating the distressed corporate shell and buying back the businesses through a pre-pack. ${ }^{111}$ Phoenixism refers to the rising of 'dead' business from the ashes of its failure through another corporate form. ${ }^{112}$ Both concepts together suggest that the practice whereby businesses are rescued for a short period of time only to fail again, to, perhaps, be rescued portends badly for business rescue more broadly.

Typically, the focus at business rescue is on maximising the pie in the interest of the stakeholders. ${ }^{113}$ It follows that the alignment of interests has attracted intense scholarly debate. ${ }^{114}$ Regard for the future survival of the rescued business has attracted comparably less attention. ${ }^{115}$ Given that rescue has a future-focused element, it is important that greater regard is accorded the discussion on how the rescue system can balance both roles of the rescue system. To that end, practices which are known to contribute to the subsequent failure of rescued businesses ought to be reconsidered. That

\footnotetext{
${ }^{110}$ Ibid, 3.11, 7.46.

${ }^{111} \mathrm{~N}$ Starling, 'Tighter rules required to prevent abuse of pre-pack administrations' [The Telegraph, July 11, 2010]; J Moules, 'Businesses urge action on 'pre-packs' [FT, Feb 19 2010].

112 J Guthrie,' Debt Dodgers Revel In Return of the Phoenix' (FT, Jan 21, 2009); Ruth Jordan, 'Government gets Previous on Pre-packs' (17/10/2011, Accountancy Age); Carl Bowes, 'Pre-packs: A Solution for Struggling Businesses?'(30/01/2012; Brendan Scott, 'Private Equity Defends Pre-packs' $(30 / 01 / 2012)$.

113 T Jackson, 'Bankruptcy, Non-Bankruptcy Entitlements, and the Creditors' Bargain' [1982] 91 Yale Law Journal 857.

114 See Section B above.

115 Nonetheless, see L Lopucki, Courting Failure: How Competition for Big Cases is Corrupting the Bankruptcy Courts (The University of Michigan Press, 2006).

${ }^{115}$ Lynn LoPucki, 'The Debtor in Full Control - Systems Failure under Chapter 11 of the Bankruptcy Code' (1983) 57 Am Bankr LJ, 247.
} 
said, much difficulty awaits those who wish to keep contractualist practices but bring them within the balanced view of rescue. Ms Graham found herself faced with these difficulties in 2014-2015 when she sought to recommend the preservation of the prepack practice while seeking to infuse the need for long-term focus for business rescue. Ultimately Ms Graham suggested reforms which she believed would make the pre-pack practice more future-focused.

The Graham review attributed the subsequent failure of businesses sold to previouslyconnected persons to the difficulty of the system to sift viable from unviable entities. ${ }^{116}$ For that reason, it proposed a viability report to be drafted by an independent expert, if the business was to be sold to those with previous connections to the failed entity. ${ }^{117}$ It also recommended that the viability report be supported by a viability statement which would indicate the problems of failed entity and outline the actions to be taken by directors going forward. ${ }^{118}$ The report proposed no reforms to the use of deferred consideration, however. The viability report and viability statement are voluntary but operate on a Comply or Explain basis. Where provided, they would be included in the dossier of documents provided to the unsecured creditors after the sale. If the previously-connected persons elect not to provide them, then they should explain their reasons and these should be brought to the notice of the creditors. ${ }^{119}$ The Graham

\footnotetext{
${ }^{116}$ n 5 above, 62 .

${ }^{117}$ Ibid, 9.11 .

118 Ibid, 9.14

${ }^{119}$ Ibid, 62-63.
} 
reforms have been introduced into the revised SIP 16 which came into effect on the $1^{\text {st }}$ of November 2015. ${ }^{120}$

It is argued that the view of rescue which seeks to balance value maximization with future survival is the preferred view of rescue. For that reason, the Graham review is commended for introducing regard for the survivability of rescued businesses into the rescue debate in England and Wales. The recommendations become more important when one explores the practice that has been cobbled together by senior lenders and their nominees in the shadow of the law, it is clear that questions relating to future survival have no place. In fact, as will be seen shortly, neither the senior lender nor the practitioner is interested in any other goal but value maximisation. It is the responsibility of the buyer to consider the potential survival of the rescued business. Perhaps the time has come to clarify or expand the role of the buyer in the rescue process; particularly in the case where they are previously connected to the distressed entity.

It is trite that only viable entities ought to be rescued. ${ }^{121}$ One would expect therefore, that there would be a clear finding of viability for distressed businesses that would be rescued. The business rescue process created by the senior lenders and their nominees does not to include that requirement. A recent report indicates that it is unlikely that the senior lender will investigate the viability of the distressed entity. In 2014, Clifford

\footnotetext{
${ }^{120}$ Accessible https://www.r3.org.uk/media/documents/technical_library/SIPS/SIP\%2016\%20Version\%203\%20Nov\%2 02015.pdf (accessed 10/04/2017).

${ }^{121}$ D Baird and R Rasmussen, 'Control Rights, Priority Rights, And The Conceptual Foundations Of Corporate Reorganizations', 8-9, (2001) https://papers.ssrn.com/sol3/papers.cfm?abstract id=278841 accessed (10/04/2017); Insolvency Law and Practice: Report of the Review Committee (Cmnd 8558,1982)Chapter 4, particularly, 53, Para 193.
} 
Chance published a report ${ }^{122}$ in response to the earlier published Tomlinson report ${ }^{123}$ on the treatment of distressed businesses in England and Wales. The former revealed more details about the bank unit to which distressed entities are transferred. ${ }^{124}$ In RBS, this was called the Business Restructuring Group (BRG). One of the reasons why a branch referred a distressed business to the BRG was for a clear determination of its viability, amongst other things. For that reason, it was that unit that was empowered to engage independent experts to assess the debtor but that tended not to happen. Typically, a desktop viability review was undertaken by the relationship manager. ${ }^{125}$ As was stated:

'The need for independent expertise may be one of the factors triggering the transfer to BRG. We note from our review of the files and discussions with the bank's employees that apart from solicitors undertaking security reviews, independent experts are not frequently engaged by BRG and those that are engaged typically have a limited remit. A full independent business review is rarely undertaken for SME customers. ${ }^{126}$

\footnotetext{
122 Clifford Chance LLP, 'Independent Review of the Central Allegation Made by Dr Lawrence Tomlinson in Banks' Lending Practices: Treatment of Businesses in Distress' http://www.rbs.com/content/dam/rbs/Documents/News/2014/04/Clifford-Chance-IndependentReview.pdf accessed 11/12/2016.

123 L Tomlinson, 'Banks' Lending Practices: Treatment of Businesses in Distress' http://www.tomlinsonreport.com/docs/tomlinsonReport.pdf, accessed 11/12/2016.

${ }^{124}$ Contrast with $\mathrm{n} 95$ above.

125 Ibid, 5.52.

${ }^{126}$ n 122 above, 5.49.
} 
It is unlikely that the practitioner will conduct a business review either, when appointed. The Insolvency Act 1986 does not require the administrator to undertake to determine the viability of distressed businesses. In fact, the Act does not require the administrator to rescue only viable entities or to dissuade previously-connected persons from rescuing non-viable businesses. The value-maximising goal of the administrator encourages her to accept the highest value offered for the distressed business, regardless of the credibility of the prospects of the rescue. As was stated in the Graham review:

\section{Insolvency practitioners with whom I spoke made clear to me that an administrator of an insolvent company cannot have regard to the likely survival of the new company. Their legal responsibility is with old company's creditors. $^{127}$}

The responsibility for determining viability falls on the buyer, therefore. It is expected that in instances where a distressed entity will be purchased by third parties, they will determine viability before the purchase and make an arm's length decision. For example, Kohlberg Kravis Roberts ('KKR'), one of the pioneers of the leveraged buyout business, noted that as a buyer, it had to investigate the target company and its business thoroughly. ${ }^{128}$ This may be one of the reasons why the companies rescued by those without previous connections fail at almost half the rate of those rescued by those with previous connections. It is therefore important that previously-connected persons are clearly required to investigate the viability of the business prior to the rescue.

\footnotetext{
127 n5 above, 7.44; emphasis mine.

${ }^{128}$ G Baker and G Smith, The New Financial Capitalists: Kohlberg Kravis Roberts and the Creation of Corporate Value (Cambridge University Press: USA 2006), 55-57.
} 
It is doubtful however, whether previously-connected persons can determine viability objectively. In fact, scholars like Baird and Jackson argue that they cannot; hence, they insist that auctions to third parties are the best way to determine viability. ${ }^{129}$ The Graham review similarly takes the view that previously-connected persons may be unable to determine viability objectively. For that reason, it recommended that the viability report be produced by an independent expert. ${ }^{130}$ In support of that recommendation, it is argued that there are important reasons for which an independent assessment of viability ought to be required when the business is to be purchased by previously-connected persons, the answers to which can be found in behavioural studies.

Behavioural scientists have demonstrated that decision-making is typically affected by a host of systematic errors in reasoning: biases. ${ }^{131}$ People are highly sensitive to loss. ${ }^{132}$ Many make decisions on short term considerations; their reference point typically being the status quo. ${ }^{133}$ Managers in particular, tend to be over- confident of their abilities to turn distressed companies around. ${ }^{134}$ As Polo has stated, the companies which are prepacked tend to be small. ${ }^{135}$ This means that there is a perfect relationship between ownership and management. The owners/managers would be the previously-connected persons to whom the distressed entities are sold. They face the prospect of losing the

\footnotetext{
${ }^{129}$ D Baird, 'Bankruptcy’s Uncontested Axioms' [1998] 108 Yale Law Journal 573.

${ }^{130}$ n 5 above, 62-63.

131 D Kahneman and A Tversky, 'Judgment under Uncertainty: Heuristics and Biases' (1974) 185 Science, New Series, 1124.

132 A Tversky and D Kahneman, 'Loss Aversion in Riskless Choice: A Reference-Dependent Model' [1991] Quarterly Journal of Economics, 1039.

${ }^{133}$ D Kahneman, J Knetsch and R Thaler, 'The Endowment Effect, Loss Aversion and Status Quo Bias' [1991] 5 Journal of Economic Perspectives, 193

134 D Lovallo and D Kahneman, 'Delusions of Success; How Optimism Undermines Executives' Decisions, [2003] Harvard Business Review, 56; U Malmendier and G Tate, Who Makes Acquisitions? CEO Overconfidence and the Market's Reaction, [2008] 89 Journal of Financial Economics 20. 135 n 94 above, 23-26.
} 
businesses that they have built from scratch, as well as their means of livelihood. ${ }^{136}$ Thus, loss aversion may impel them to seek to preserve the status-quo by preserving even lame ducks, if given the chance. ${ }^{137}$ When we also consider the fact that they are also likely to be buoyed by the optimism that they can turn the businesses around, it is clear that they are likely to accept the challenge of the second chance even with businesses that are not necessarily viable; hence the importance of an independent finding of viability.

It is common to see the argument that companies which require rescue are merely financially, not economically distressed. ${ }^{138}$ It is more likely, however, that even financially distressed businesses also have operational problems that must be resolved, if they are to carry on successfully post-rescue. This observation is hardly novel. Arthur Dewing, a leading finance scholar, highlighted the failure to properly diagnose the debtor's operational problems as a reason for the subsequent failure of rescued entities, as far back as the nineteenth century. ${ }^{139}$ Similarly, turn-around doctors state that an assessment of the state of the business, the causes of the distress and the operational needs going forward are crucial to the formation of a sustained recovery strategy for distressed entities. ${ }^{140}$ They state that the exercise is deemed successful when the

\footnotetext{
${ }^{136} \mathrm{n} 5$ above, 7.51 .

137 Kerkman, 'The Debtor in Full Control: A Case for Adoption of the Trustee System' (1987) 70 Marquette Law Review 159.

138 n 81 above, 16.

139 A Dewing, 'The Procedure of Contemporary Railroad Reorganization' [1919] 9 American Economic Review, 1; The Financial Policy of Corporations (Ronald Press Company, New York, 1921), Vol.5, 'Failure and Reorganization', 232-233; 'The Theory of Railroad Reorganization' (1918) 8 American Economic Review 774, 777-778.

140 O Kharbanda and E Stallworthy, Company Rescue: How to Manage a Business Turnaround (WilliamHeninemann Ltd 1987) 27-29.
} 
company recovers from its steady plunge and its fortunes are reversed. ${ }^{141} \mathrm{KKR}$, our example of a third-party buyer, has stated that it typically had to identify the areas in which the distressed entities it had purchased could improve their cash-flows if it was to make profits in its investment; given that it made profits only where its investments turned over a profit. That required the retention of some of the old management and the engagement of other professionals with requisite experience to oversee the process of drafting and executing a recovery plan. ${ }^{142}$ In addition, recent empirical studies reiterate the finding of Hotchkiss, that businesses which go into a formal insolvency process show obvious signs of economic distress in the period leading to the filing. ${ }^{143}$

Clearly, it is important to investigate the reasons for the distress and create a plan to prevent future distress but these requirements for sustained rescues are not addressed in the process created by the senior lenders. The Clifford Chance report identified above shows the difficulties the bank has dealing with operational, not financial issues. ${ }^{144}$ It indicates that a restructuring strategy is generated only for those debtors that are deemed viable by the bank but these return to branch, they do not go into the insolvency system. ${ }^{145}$ Even in that event, much of the restructuring involved financial issues, not operational. The entities that go to sale have no plans created to fix their operational problems. The Insolvency Act 1986 makes no requirement for an operational plan. The practitioners have constantly stressed that they are not responsible for the future of the

\footnotetext{
${ }^{141}$ O Kharbanda and E Stallworthy, Corporate Failure: Prediction, Panacea and Prevention (McGrawHill Book Company (UK) Ltd, 1985), Chapter 15

142 n 128 above, 76.

143 B Adler, V Capkunb and L Weiss, 'Destruction of Value in the New Era of Chapter 11' (2013) 29 Journal of Law, Economics and Organization, 461; E Hotchkiss, 'Postbankruptcy Performance and Management Turnover' (1995) 50 Journal of Finance 3.

${ }^{144} \mathrm{n} 122$ above, 6.21 .

145 Ibid, 5.62.
} 
rescued business; their responsibility being to maximise recoveries for the creditors of the distressed entity. They will therefore not put forward plans for operational changes. Hence, the responsibility for operational rescue falls on the buyer. The viability statement recommended by the Graham review is therefore essential for the rescue process. It will improve the chances that the future operational needs of the business will be considered and outlined.

Even if we focus solely on financial distress and the financial structure of the rescued entity, we see that there are serious problems. $39 \%$ of pre-packs rescued with deferred consideration are failing again, whereas only $9.7 \%$ of their counter-parts sold without deferred consideration are failing again. ${ }^{146}$ In trading administrations, $37.5 \%$ of those rescued with deferred consideration are failing again, while $14.5 \%$ of their counterparts fail again with 36 months. It is therefore important that we focus in greater detail on the use of deferred consideration. It is important first to deal with its nature. When consideration is deferred, it means that the price to be paid for the purchase of the distressed business is not paid contemporaneously with the transfer. ${ }^{147}$ The new company undertakes to pay the sum within the period specified or agreed by the parties. Put differently, the new company incurs a debt because of its purchase of the business. Debt, as we know, is fixed cost which must be paid regardless of the company's profit margin. Deferred consideration tends to be secured in the case of pre-packs. ${ }^{148}$ The Graham review was concerned with the ability of the new company to repay the debt. ${ }^{149}$

\footnotetext{
${ }^{146}$ n 53 above, A4.1.2.

147 n 5 above, 7.57 .

148 Ibid, 41; R Milkins, Guide to Earn Outs and Deferred Consideration December 2012 http://www.roxburghmilkins.com/images/resources/Earn_Outs_and_Deferred_Practice_Note.pdf, last accessed 20/09/2016.

${ }^{149}$ Ibid, 40 - 42; n 53 above, A 2.2 .
} 
It found that the debt was typically repaid within 12 months by most companies. ${ }^{150}$ It is clear however, that most of them failed with the next 12 to 24 months after completing the payment. $^{151}$ Interestingly, the Graham report chose not to make any recommendations in that regard.

When we examine rescue processes over the past century, we find that as far back as the nineteenth century, distressed businesses have been rescued in circumstances in which some debt is carried forward. ${ }^{152}$ By the last decade of that century, however, stakeholders interested in more sustained rescues came to recognise that the business could only survive where it carried forward lower thresholds of debt than had been the practice. ${ }^{153}$ They recognised also, that the debt carried forward had to be brought within reasonable percentage of the projected earnings of the rescued business. ${ }^{154}$ In addition, that the period following the completion of the rescue process was the most crucial. ${ }^{155}$ We can apply this received wisdom to the situation in England and Wales. It is unclear whether the amount of deferred consideration is calculated in relation to the future earning capacity of the rescued business. It is possible and in fact likely, that the rescued businesses are fatally leveraged going forward. Further, it is important to consider whether the allocated time frame within which the deferred sum is extracted is adequate. Ideally, a fair balance ought to be reached between the desire of the secured lenders and other creditors to be repaid and the broader desire to have sustained rescue.

\footnotetext{
${ }^{150}$ Ibid, 40 - 42; n 53 above, A 2.2.

${ }^{151}$ Ibid, A4.1.2.

152 S Daggett, Railroad Reorganization (Reprint Bear Books, 2010); Francis, Stetson (ed), 'Some Legal Phases of Corporate Financing, Reorganization and Regulation' (Reprint General Books LLC, 2009) 247.

153 Ibid, 247-248

${ }^{154}$ F Cleveland and F Powell, Railroad Finance (D Appleton and Company, 1912, New York and London), Chapter IV, 261.

${ }^{155}$ W Ripley, Railroads: Finance \& Reorganization (Longmans, Green, and Co, New York, 1915), 403.
} 
The question that follows is to whom to allocate the responsibility for a fair consideration of both the interests of the beneficiaries of the deferred consideration typically the senior lenders - and of the rescued business going forward. As with the viability and operational questions, the senior lender is obliged to consider only its interests. The insolvency practitioners who would be in a position, given their experience, to give relevant advice to the business carried forward are not obligated to encourage those rescuing the business to negotiate a better deal. In fact, they are likely to take advantage of such a deal if it results in higher returns to the pre-distress creditors. ${ }^{156}$ As was stated in the Graham review:

Old company's creditors are best served by the administrator negotiating the best possible deal with the purchaser (and the administrator cannot concern $\underline{\text { him/herself with whether or not the purchaser cannot }}$ afford it). ${ }^{157}$

The responsibility therefore falls on the buyer. Where they do not seek adequate independent advice, the business is likely to fail again. Where almost 1 in every 2 businesses that are rescued by deferred consideration fail again, it is important to reconsider the extant approach to the use of deferred consideration in the rescue process.

\footnotetext{
${ }^{156}$ n 5 above, 7.44 .

${ }^{157} \mathrm{n} 5$ above, 7.44; emphasis mine.
} 
The Graham review placed its recommendations on a Comply or Explain basis. Generally, the Comply or Explain approach has its advantages. ${ }^{158}$ It is flexible. It enables companies to focus on substance, while operating at their own pace. As stated already, a large proportion of the companies that use the pre-pack sale to previouslyconnected persons tend to be SMEs. They would benefit from the proportionality of the Comply or Explain approach; at least in terms of cost. Thus, a voluntary approach is understandable. Comply or Explain is not without its challenges, however. Considerable institutional support is required to enable the system work effectively. ${ }^{159}$ In corporate governance through which this approach was launched, the parties to whom the information is to be disclosed are empowered to take concrete action against the subject of the duty where compliance is weak. ${ }^{160}$ In the case of business rescue, the legal rights and powers of the pre-distress stakeholders terminate after the rescue proceedings. They have no legal rights against the new company even where the viability report and viability statement are insufficient.

Further, in Corporate Governance, there is the Financial Reporting Council ('FRC') which, amongst others, engages in oversight functions and contributes actively to the development of various elements of the corporate governance process. ${ }^{161}$ For example, the FRC has been involved in monitoring explanations and the quest to improve their

\footnotetext{
158 ICAEW, 'When is comply or explain the right approach?' http://www.icaew.com//media/corporate/files/technical/corporate-governance/dialogue-in-corporate-governance/icaew-tl-q3web.ashx?la=en accessed 11/12/2016, 
quality. ${ }^{162}$ The Graham Review recommended the creation of a body of experts to oversee the decision to pre-pack, called the Pre-pack Pool. ${ }^{163}$ While the pre-pack pool may exercise oversight over issues relating to the transparency of the decision to prepack where approached, its functions do not extend to matters related to recidivism. It has no oversight functions over the independent viability report or the viability statement or the explanations where those are presented in lieu. ${ }^{164}$ The administrator does not review the documents either. Her role is to present them to the creditors.

Crucial elements of Comply or Explain are absent. For that reason, it is doubtful that it can operate successfully in the realm of business rescue. It is argued, therefore, that the Comply or Explain route ought not to be the recommended approach. The following section proposes alternative reforms that would better promote due consideration for the future survival of the rescued entity.

\section{Proposals to Improve the Effectiveness of the Business Rescue Process}

Polo has argued that both the initial and subsequent failure of businesses sold to previously-connected persons are not related to their misdeeds but attributable to the fact their businesses are much smaller than those sold to their non-connected counterparts, operate in human-capital intensive industries and lack alternative prospects. ${ }^{165}$ The assumption appears to be that such businesses would struggle more in comparison to their larger counterparts following the completion of the rescue

\footnotetext{
162 Financial Reporting Council, What Constitutes an Explanation Under 'Comply or Explain'? Report of Discussions between Companies and Investors', February 2012.

${ }^{163}$ n 5 above, p59; SIP 16.

164 n Error! Bookmark not defined. above, 602-603.

${ }^{165}$ n 94 above, 23-26.
} 
process. ${ }^{166}$ It may be that our smallest reorganising businesses need more guidance if they are to effect sustainable rescues. They clearly do not receive the said guidance from the senior lenders or the administrators. Consequently, it is argued that the independent viability review and viability statement on the future steps to be taken by the directors should be made mandatory whenever previously-connected persons are to rescue a distressed entity. On one hand, such an approach will signal to directors that a timely and pro-active approach to rescue is important; on the other, it will enhance the chances that they will be able to access relevant independent advice.

As we have seen, deferred consideration appears to be even more likely to contribute to the subsequent failure of the company as $39 \%$ of the pre-packs characterised by deferred consideration fail subsequently; while $37.5 \%$ of trading administrations characterised by deferred consideration fail subsequently. ${ }^{167}$ As has been indicated above, it is important to focus on the earnings to deferred consideration ratio and the time-span for repayment. As it currently stands, it is unclear whether there is a clear link between the percentage of new earnings which the company can safely pay towards the repayment of the debt, while maintaining a good profit margin, and the amount of deferred consideration carried forward by the new company. Neither the Insolvency Act 1986 nor SIP 16 includes such a requirement. As we have also seen, neither the senior lender nor the administrators are obliged to dissuade the debtor from undertaking a fatal amount of leverage going forward. It is therefore recommended that the SIP 16 and the Insolvency Act 1986, ought to be amended to require the buyers to demonstrate that they have taken independent advice on the earnings to deferred consideration ratio and

\footnotetext{
${ }^{166}$ Ibid, 25.

${ }^{167}$ n 53 above, A4.1.2; B4.1.2.
} 
the time-span negotiated for the repayment of the debt. This requirement should apply even where the buyers do not have previous connections with the distressed company because the Wolverhampton study showed that recidivism related to deferred consideration is not limited to situations where the buyer had a prior relationship to the failed entity.

One of the challenges that would face previously-connected persons who wish to rescue distressed business in a regime that requires a mandatory viability review and operational statement is that of cost. Professionals must be paid at a point when there is little or no money available. Such requirements are likely to dissuade some of such persons from undertaking rescues. These arguments must however be balanced by the clear recognition that the failure to create a viable plan is likely to result in future failure of the rescued business, the costs of which will be borne by the future stakeholders. One method by which to reduce overall costs is to combine both the operational and viability statements, particularly in the case of smaller businesses. It is important however, that they have an objective review of their plans, as well as assistance in developing viable plans. The independent expert is not expected to create or guarantee the creation of a fool-proof plan. What is required is a statement on whether the proposed plan is likely to facilitate the future survival of the rescued entity. It is expected that where the business really is viable and has a clear plan for future survival, the buyer will be able to access funds to cover the cost of the viability/operational statement. Also, where such a requirement will deter spurious rescue attempts, it is a welcome, rather than a worrying development. 
There are of course other challenges facing the rescue system as a whole. The scope of the floating charge and its ability to cover after acquired assets is one important aspect. Access to rescue finance which would facilitate the rescue process is another. Rescue finance would cover some of the additional costs to be introduced by an obligatory system described in this article. Where the additional powers are given to facilitate rescue by previously-connected persons, it becomes even more important to impose clear responsibilities on them in the interests of sustained rescues. These are issues which go to the very heart of rescue and the nature of the system that operates in a particular jurisdiction. These issues, as well as those discussed in this article, ought to be addressed in a more comprehensive debate on the nature of rescue and the features of our preferred rescue process. Such a discussion would hopefully prompt a more comprehensive review of the system; an outcome which is preferred to the piece-meal changes that have taken place. It is important that such debate and reform recognise the need for a future-focused rescue system which seeks to balance value maximization with the survivability of the rescued business, however.

\section{E. Conclusion}

It is generally accepted that the value in financially distressed businesses ought to be maximised for the benefit of all pre-distress stakeholders. Rescue systems and other contractualist processes have been developed to achieve that goal. In England and Wales, both the administration process and its pre-pack variant have been created with value maximization in mind. Together, they account for the greater proportion of business rescues; with more business rescues effected through by the latter than the former. Pre-packs and similar contractualist processes have thrived on the argument that 
many of these companies require quick sales to stem the haemorrhage of value following the public acknowledgement of the distress; particularly in instances in which the companies are unable to access trading finance.

As with contractualist systems generally, the pre-pack process is skewed in the interest of the senior lenders who exert considerable control over its commencement, administration and outcomes. They have therefore been criticised by those who argue that senior lenders and their nominees lack the incentive to maximise the value in the assets; particularly where they are over-secured. A competing view argues that these processes reduce the cost of financial distress. Further, that in most cases, the senior lender is under-secured and so would typically seek to maximise value. While such discussions are pertinent, it is equally important to consider the effect of these contractualist processes on the post-rescue survivability of distressed entities.

Pre-packs tend to be augmented by sales to persons with previous connections to the distressed entity and sales with the aid of deferred consideration to improve the chances of achieving going-concern sales. However, both factors have been associated with the likelihood that the rescued business will fail again. Almost half of the businesses rescued with deferred consideration and almost a third of those rescued by previouslyconnected persons fail within the next 36 months. A distressed business is almost twice as likely to fail again within the stated period when rescued by previously-connected persons, than when rescued by their unconnected counterparts and almost 4 times as likely to fail when rescued with deferred consideration, than when it is not so rescued. With almost 8 out of every 10 going-concern sales, having at least one of these factors, the policy-maker was right to be concerned. 
The recidivism-related reforms which ensued were predicated on the notion that there is an inherently future-focused element of rescue. Thus, it is important for the rescue system to balance value-maximization with the prospect of future survival. This is particularly important if the system is to inspire the trust of wider stakeholders. It is on that basis that the processes created by the senior lenders and their nominees should be examined. While some of their practices are innovative, they do not seek to balance these two goals of rescue. Recent studies on the Business Support Unit to which distressed entities are sent before formal entry into the rescue process show that senior lenders do not make detailed investigations into the viability of the business or its operational needs going forward. Similarly, the Insolvency Act does not require the practitioner to undertake either inquiry. What's more, practitioners have indicated that their responsibilities are to the extant stakeholders, at best. In practice, it is common knowledge however, that they tend to act in the interest of the senior lender. In either case, they are past-focused, seeking to maximise recoveries, not future-focused to guide the distressed business to a viable second chance.

Ultimately, the responsibility falls on the buyer to consider the future survival of the rescued business. While third parties are better able to make arm's length decisions however, previously-connected persons appear to require additional help. It is therefore pertinent to set out additional responsibilities for these parties where they wish to rescue distressed businesses. For that reason, The article agrees with the introduction of the independent viability report and viability statement which look to the future of the rescued business. Nevertheless, given the difficulties of enforcing the Comply or Explain method, The article argues that the requLikirements ought to be obligatory. Unlike the Graham review, The article argues that the reforms should extend to the use 
of deferred consideration. It argues that the buyer ought to demonstrate that it has obtained independent advice on the earning-projection-to-deferred consideration ratio, as well as on the time-span negotiated for the repayment of the debt. Further, that this requirement should apply even where the parties have no previous connections with the distressed company because failure related to deferred consideration is not limited to cases where the buyer had previous connections with the distressed entity.

The article recognises that its recommendations could increase the costs of the rescue process and deter some rescue attempts. It is important to recognise that these are issues on which the buyer is already expected to obtain independent advice. All that The article recommends is a demonstration that the said advice has been sought and obtained. The case for independent advice is strengthened by the fact that the buyer cannot or ought not to rely on the insolvency practitioner whose remit is to seek the highest value, not help the buyer develop a sound plan. Similarly, the practitioner is not obliged to advice the buyer on the amount of leverage to take forward or the repayment schedule that is best suited to the needs of the rescued business. Nevertheless, The article argues that the cost can be reduced for small businesses by fusing the viability report and viability statement. Further, that the buyer should be able to access funds with which to pay for the advice if it can convince potential lenders of the soundness of the business and its prospects. To the extent that the recommendations dissuade buyers with spurious rescue plans however, then they are even more welcome.

The pre-pack process is an important feature of the rescue process. Nonetheless, it is important to scale back elements that are detrimental to effective business rescue. This article argues that effective rescue balances value maximization with the future survival 
of rescued entities. To enhance the chances of the latter, there are several changes that would be necessary which cannot be discussed satisfactorily in this article. It is important however, that any changes to the rescue process should include the clarification of the duties of the buyer and the responsibilities which they should undertake if the desired balance is to be achieved. 